\title{
Biological Activities of the Alkaloid Quinazoline Extracted from Aspergillus nomius
}

\author{
Mohamed I. A. Ali, Ahmed H. Abd El-Fattah*, Neveen M. Khalil ${ }^{\#}$ and \\ Mohamed S. Sayed \\ Department of Botany \& Microbiology, Faculty of Science, Cairo University, Giza \\ 12613 and ${ }^{*}$ Department of Natural Products, National Research Center, Giza, Egypt.
}

\begin{abstract}
TWENTY FIVE Aspergillus isolates were screened from Giza Governorate and Saint Catherine Protectorate soils in Egypt. The antimicrobial activity of the crude extracts was tested against two Gram positive bacteria (Bacillus subtilis NRRL-B-4219, Staphylococcus aureus ATCC29213), four Gram negative bacteria (Alcaligenes faecalis B-170, Escherichia coli ATCC25922, Klebsiella pneumoniae ATCC10131, Pseudomonas aeruginosa ATCC27953), and one yeast (Candida albicans ATCC10231). The antioxidant activity using free radical scavenging model was assayed for the crude extracts. The antitumor activity for all of crude extracts was determined against HCT116 (Colon carcinoma cell line), HEPG2 (Liver carcinoma cell line), and MCF-7 (Breast carcinoma cell line). Aspergillus nomius was the most potent fungal species accordingly, it was chosen for bioactivity assay. Identification of this species was further confirmed at the molecular level based on nuclear ribosomal DNA 18s identities. An accession number, LC199488, was given at the DDBJ GenBank. The column chromatography of its crude extract yielded five distinguished fractions. The biological (antimicrobial, antioxidant and antitumor) activities of these fractions were assayed. Fraction B proved to be of most potential. HPLC analysis of this fraction showed that there was a sharp and clear peak at about $18.1 \mathrm{~min}$. This denoted the presence of an active compound. The compound at this peak was purified and its structure was elucidated via ${ }^{1} \mathrm{HNMR}$ and ${ }^{13} \mathrm{CNMR}$ spectroscopy. It was concluded that it would be 1,2,3,9 tetrahydropyrrolo [2,1-b] quinazolin-3-ol.
\end{abstract}

Keywords: Aspergillus nomius, Secondary metabolites, Antimicrobial, Antioxidant, Anticancer.

\section{Introduction}

Aspergilli grow abundantly as saprophytes on decaying vegetation and have been found in large numbers in moldy hay, organic compost piles and leaf litter (Machida \& Gomi, 2010). Their prevalence in the natural environment, their ease of cultivation on laboratory media and the economic importance of several species ensured that many mycologists and industrial microbiologists were attracted to their study.

The importance of Aspergilli had been demonstrated long time ago as potential sources of many pharmaceutical leads. They were reported to produce novel bioactive metabolites as antimicrobial, antioxidant, anticancer, and antiviral agents. The Nigri section consists of six commonly found species (excluding A. aculeatus and its close relatives) from which currently
145 different secondary metabolites have been isolated and/or detected (Nielsen \& Mogensen, 2009 and Yang et al., 2017).

Aspergillus insuetus, A. calidoustus and the closely related $A$. pseudodeflectus were isolated from diseased human tissue in Europe (Houbraken et al., 2007). All produced drimanes, both $A$. calidoustus and $A$. insuetus produce dophiobolins $\mathrm{G}$ and $\mathrm{H}$, whereas only A. calidoustus produced austins, compared with pergillin-like metabolites and many unknown metabolites biosynthesized by $A$. insuetus and A. pseudodeflectus, respectively. Additionally, the TMC-120s were first reported as secondary metabolites of $A$. ustus (TC1118) isolated from rhizosphere of grass (Kohno et al., 1999a, b). TMC-120 B has been isolated from $A$. pseudodeflectus (Ogawa et al., 2004 and Slacka et al., 2009) and ester derivatives of the drimane

"Corresponding author email: neveen@sci.cu.edu.eg, Tel: +201003643976 
from A. ustus var. pseudodeflectus (Hayes et al., 1995 and Slacka et al., 2009).

N-(3-4-Dichlorophenyl) 2-Methyl, 2,3 Dihydroxypropio amide was isolated from A. fumigatus, this product induced apoptosis through increasing activation of caspase 3 and caspase 9 which lead to programmed cell death (Osman et al., 2007). Other two active compounds were isolated from the broth of $A$. fumigatus isolated from Brazil soil of the culture grown in the presence of pooled bacteria and were identified as 3,4-dimethoxyphenol and 1,3,5-trimethoxybenzene which has antimicrobial activity (Furtado et al., 2002).

The aim of this work was to isolate some Aspergillus spp. and screen them for production of secondary metabolites that may contain bioactive compound and to study the antimicrobial, antioxidant and anticancer activities of these compounds.

\section{Materials and Methods}

Isolation and identification of Aspergillus spp.

For isolation of Aspergillus species, seven soil samples of agricultural soil were collected, two of them from Saint Catherine Protectorate and the other samples were obtained from Giza Governorate, Egypt. Fungal isolation was carried out according to Johnson et al. (1960) using soil dilution plate method. Czapek-Dox's medium was used for isolation which contained $(\mathrm{g} / \mathrm{l})$ : sucrose, $30.0 \mathrm{~g} ; \mathrm{NaNO}_{3}, 2 ; \mathrm{K}_{2} \mathrm{HPO}_{4}, 1 ; \mathrm{MgSO}_{4} .7 \mathrm{H}_{2} \mathrm{O}, 0.5$; $\mathrm{KCl}, 0.5$; $\mathrm{FeSO}_{4} .7 \mathrm{H}_{2} \mathrm{O}$; 0.001; agar, 18 and final $\mathrm{pH}$ was adjusted at $7.0( \pm 0.2)$. Streptomycin $(30 \mu \mathrm{g} / \mathrm{ml})$ was added to the above medium after autoclaving and cooling. Identification of the developed fungal colonies up to species level was based on their morphological and microscopic characters according to Thom \& Raper (1945), Raper \& Fennell (1965) and Moubasher (1993).

Extraction of secondary metabolites from Aspergillus spp.

Each Aspergillus sp. was grown on CzapekDox with yeast extract agar at $28^{\circ} \mathrm{C}$ for 7 days and spores were harvested with a sterile solution of $1 \%$ Tween $80(\mathrm{v} / \mathrm{v})$, and $0.9 \% \mathrm{NaCl}(\mathrm{w} / \mathrm{v})$ to prepare the spore buffer suspension (Campoy et al., 2010). The concentration of spore suspension was determined by a hemocytometer and adjusted to $2 \times 106$ spores $/ \mathrm{ml}$. One $\mathrm{ml}$ of spore suspension was inoculated into $250 \mathrm{ml}$ minimal medium (Pontecorvo et at., 1953), with some modifications, in $500 \mathrm{ml}$ Erlenmeyer flasks and incubated at $30^{\circ} \mathrm{C}$ in shaking incubator $(200$ rpm). After 7 days of incubation, the fungal mats were filtered by cheese cloth. The modified minimal medium contained (g/l): Glucose $10 \mathrm{~g}$, trace elements solution $1 \mathrm{ml}, 50 \mathrm{x}$ salt solution 20 $\mathrm{ml}$ and L-glutamine $66.5 \mathrm{ml}$. The trace elements solution contained (mg/l): $\mathrm{Na}_{2} \mathrm{~B}_{4} \mathrm{O}_{7} .10 \mathrm{H}_{2} \mathrm{O} 40.0$ $\mathrm{mg}, \mathrm{CuSO}_{4} .5 \mathrm{H}_{2} \mathrm{O} 400.0 \mathrm{mg}, \mathrm{FeSO}_{4} .7 \mathrm{H}_{2} \mathrm{O} 800.0$ $\mathrm{mg}, \mathrm{MnSO}_{4} \cdot 4 \mathrm{H}_{2} \mathrm{O} 800.0 \mathrm{mg}, \mathrm{Na}_{2} \mathrm{MoO}_{4} \cdot 10 \mathrm{H}_{2} \mathrm{O}$ $800.0 \mathrm{mg}$, and $\mathrm{ZnSO}_{4} .7 \mathrm{H}_{2} \mathrm{O} 8.0 \mathrm{~g}$. The $50 \mathrm{x}$ salt solution contained (g/l): $\mathrm{KH}_{2} \mathrm{PO}_{4} 76.0 \mathrm{~g}$, $\mathrm{MgSO}_{4} .7 \mathrm{H}_{2} \mathrm{O} 26.0 \mathrm{~g}, \mathrm{KCl} 26.0 \mathrm{~g}$, and chloroform $2 \mathrm{ml}$. L-glutamine concentration $4.4 \mathrm{~g}$ in $100 \mathrm{ml}$ Dist. $\mathrm{H}_{2} \mathrm{O}$.

The culture filtrates were extracted by ethyl acetate $(1: 1, \mathrm{v} / \mathrm{v})$ and the supernatant was then extracted three times with equal volume of ethyl acetate $(1: 1, \mathrm{v} / \mathrm{v})$. The upper organic phase of supernatants were combined and concentrated to dryness under reduced pressure using a rotary evaporator (Heidolph) to obtain the crude fungal extract.

\section{Antimicrobial activity}

The antimicrobial activity of the extracts was assayed against two Gram positive bacteria (Bacillus subtilis NRRL-B-4219, Staphylococcus aureus ATCC29213), four Gram negative bacteria (Alcaligenes faecalis B-170, Escherichia coli ATCC25922, Klebsiellapneumoniae ATCC10131, Pseudomonas aeruginosa ATCC27953), and one yeast (Candida albicans ATCC10231). The assay was performed according to Sahin et al. (2003) with some modifications. Media used for testing bacteria were nutrient agar (NA) contained (g/l): Beef extract 1.0, yeast extract 1.0, peptone 5.0, and $\mathrm{NaCl}$ 5.0, and Czapek-Dox's agar media for yeast test. The test organisms were cultured in Petri dishes for $72 \mathrm{~h}$ at $37^{\circ} \mathrm{C}$. After incubation the growing colonies were scrapped off the agar and transferred to nutrient broth solution. McFarland 0.5 was used as turbidity standard (McFarland, 1907). Absorbance of the suspension was measured at $550 \mathrm{~nm}$ to obtain 10-7 CFU/ml. One hundred $\mu$ of nutrient broth was added to each well in 96 well plate in triplicates, $100 \mu \mathrm{l}$ of each sample of the extracts dissolved in $10 \%$ dimethylsulfoxide (DMSO), were first diluted to the highest concentration $(500 \mu \mathrm{g} / \mathrm{ml})$ to be tested. The positive control was erythromycin in case of bacterial strains, while amphotericin B in case of C. albicans ATCC10231. Double dilutions were made for each sample discarding the last $100 \mu \mathrm{l}$. 
Then $100 \mu \mathrm{l}$ of bacterial and Candida solutions were added to each well. The plates were sealed with parafilm and incubated at $37^{\circ} \mathrm{C}$ for $24 \mathrm{~h}$. After incubation, $40 \mu \mathrm{l}$ of p-iodonitrotetrazolium violet salt (INT) $(0.2 \mathrm{mg} / \mathrm{ml})$ were then added to the wells. The plates were then incubated again until a purple color develops. The minimum inhibitory concentration (MIC) was determined by observing the turbidity of INT. The lowest concentration that shows no turbidity (purple) is recorded as the MIC value.

In vitro antioxidant activity using free radical scavenging (FRS) model

The assay was performed according to Hamed (2009) with some modifications. One $\mathrm{mg}$ of ethyl acetate of each of the fungal extracts were dissolved in $1 \mathrm{ml}$ DMSO to prepare stock solution of $1000 \mu \mathrm{g} / \mathrm{ml}$. DPPH $(0.004 \mathrm{mg})$ was dissolved in $100 \mathrm{ml}$ of methanol HPLC grade to prepare $0.004 \%$ solution, it must be stored in dark until use. Different concentrations (5-25 $\mu \mathrm{g})$ of reference standard compounds (Vitamin $\mathrm{C}$ and Quercetin) were prepared.

In each well of 96-well plate, $20 \mu$ of stock solutions (samples-or standard) was added followed by addition of $180 \mu \mathrm{l}$ of methanolic solution of DPPH $(0.004 \%)$ to reach the final maximum concentration of tested samples 100 $\mu \mathrm{g} / \mathrm{ml}$. The reaction mixture was incubated for $30 \mathrm{~min}$, and at the end of incubation time the plate was measured at $\lambda=540 \mathrm{~nm}$ by microplate reader. Negative controls were done to correct the absorbance of colored extracts to avoid the interference. Blank was measured by replacing $20 \mu \mathrm{l}$ of samples by $20 \mu \mathrm{l}$ of dissolving agent (DMSO). The assay was run in duplicate and repeated at least once for active extracts. The radical scavenging activity of fungal extracts and calibrator can be calculated from the following equation:

$\%$ of Scavenging Activity $=[(\mathrm{A}$ Blank $-\mathrm{A}$ Sample) / A blank] x 100

where, A Blank (Absorbance of reaction mixture without test sample "DPPH only"), A Sample (Absorbance of reaction mixture in presence of test samples).

\section{Cytotoxicity assay against tumor cell lines}

The preliminary assays of all samples were based on single dose of the fungal extracts in culture medium with concentration of $200 \mu \mathrm{g} /$ $\mathrm{ml}$ for all of crude extracts and $50 \mu \mathrm{g} / \mathrm{ml}$ for the column fractions, against HCT116 (Colon carcinoma cell line), HEPG2 (Liver carcinoma cell line), and MCF-7 (Breast carcinoma cell line). It was determined by colorimetric SulfoRhodamine-B stain (SRB) method (Skehan et al., 1990). A reference cytotoxic compound (potassium dichromate $\mathrm{K}_{2} \mathrm{Cr}_{2} \mathrm{O}_{7}$, a known DNAdamaging agent) was used as positive control for cytotoxicity. Treated plates were incubated for $72 \mathrm{~h}$ before being subjected to cytotoxicity measurement by SRB.

The assay was done on cell line monolayers of HCT116, HEPG2, and MCF-7 cells in the tissue culture plates. The cells were plated in 96-multiwell plate (104 cells/well) for $24 \mathrm{~h}$ before treatment with the extracts. The extracts added to the cell monolayers triplicate reached final concentration of $200 \mu \mathrm{g} / \mathrm{ml}$. Wells were prepared for each individual dose. The monolayer cells were incubated with the extracts for $48 \mathrm{~h}$ at $37^{\circ} \mathrm{C}$ and in humidified atmosphere of $5 \% \mathrm{CO}_{2}$. After $48 \mathrm{~h}$, cells were fixed by adding of trichloroacetic acid (TCA) in each well for $1 \mathrm{~h}$. Then they were washed five times with tap water to remove TCA. The cells were then stained for 30 min with $0.4 \%$ (w/v), Sulfo-Rhodamine-B (SRB) stain dissolved in $1 \%$ acetic acid. Unbound dye was removed by four washes with $1 \%$ acetic acid, and proteinbound dye was extracted with $10 \mathrm{mM}$ unbuffered Trisbase [tris-(hydroxymethyl) aminomethane] for determination of optical density in a computerinterfaced. The color intensity was measured in an ELISA reader at $564 \mathrm{~nm}$. Cell-free blank was used for background correction of the absorbance. The viability was calculated as a percentage relative to the solvent control absorbance value after subtracting the contribution from cell-free blank. The results were represented as viability $\%$ or cytotoxicity $\%$ (obtained by subtraction of the $\%$ viability value from 100 ).

The most promising bioactive fungal species was subjected to confirmatory molecular identifications.

\section{Molecular identification of the most potent Aspergillus sp.}

Identification of the most potent Aspergillus sp. Isolated from Giza Governorate was further confirmed using nuclear ribosomal DNA internal transcribed spacer (ITS) sequencing. Genomic DNA was isolated using GenElute bacteria 
Genomic DNA Kit with some modifications (Catalog No. NA2100). Internal transcribed spacer (ITS) region of 18S rRNA was amplified using the primer pair nu-SSU-0817: TTAGCATGGAATAATRRAATAGGA and nuSSU-1196: TCTGGACCTGGTGAGTTTCC which amplifies a fragment of 420 base pairs (Borneman \& Hartin, 2000). Sequencing of PCR amplified product was performed at Macrogen (South Korea). The resulting sequence was entered into the BLAST algorithm of DDBJ "DNA Data Bank of Japan" Gen Bank databases to obtain closely related phylogenetic sequences. A phylogenetic tree was constructed using Mega7 software. The obtained sequence was then submitted to DDBJ Gene Bank data bases to obtain an accession number.

\section{Large scale production of the bioactive secondary metabolites}

The fungal species Aspergillus nomius was cultivated on minimal medium (30 liter), 250 $\mathrm{ml}$ medium in $500 \mathrm{ml}$ Erlenmeyer flasks by inoculation of $100 \mu \mathrm{l}$ from spore suspension. The fermentation culture was incubated at $30 \pm 2^{\circ} \mathrm{C}$, with $140 \mathrm{rpm}$ shaking for one week. Mycelia were filtered and the filtrate (aqueous phase) was subjected to mixing and agitation with ethyl acetate $(1: 1, \mathrm{v} / \mathrm{v})$ three times for complete extraction, and the ethyl acetate phase (organic phase) was collected for further processing. All of the ethyl acetate (organic fractions) were combined and dried under vacuum using rotary evaporator at $50^{\circ} \mathrm{C}(200 \mathrm{rpm})$. The dried crude extract (about $15 \mathrm{~g})$ was subjected to chromatographic methods for purification of fungal active metabolites.

\section{Column chromatography}

Aspergillus nomius crude extract (15 g) was subjected to silica gel (0.2-0.5 $\mathrm{mm}$ mesh size) column chromatography, silica gel was soaked in $\mathrm{H}_{2} \mathrm{O}-\mathrm{MeOH}$ mobile phase solvent system (50:50, $\mathrm{v} / \mathrm{v}$ ) overnight and then packed in the column, eluted with $\mathrm{H}_{2} \mathrm{O}-\mathrm{MeOH}$ gradient until $100 \% \mathrm{Me}$ $\mathrm{OH}(20 \%$ stepwise), then the mobile phase was changed to $\mathrm{MeOH}$ - EtOAc in gradient manner until 100\% EtOAc. Two hundred and fifty $\mathrm{ml}$ from column fractions were collected.

Analytical TLC was carried out using TLC aluminum sheets silica gel 60 F-254 (Merck). A capillary tube was used to apply a small amount of the crude extract to a the TLC plate, and developing those spots with appropriate solvent systems under saturated conditions (3\%, 5\%, 10\% Methyl alcohol: dichloroethylene), Chromatograms were detected under UV light (254 and $365 \mathrm{~nm}$ ), sprayed with a coloring agent vanillin- $\mathrm{H}_{2} \mathrm{SO}_{4}$ (one gram vanillin dissolved in $100 \mathrm{ml}$ of $5 \% \mathrm{MeOH}-\mathrm{H}_{2} \mathrm{SO}_{4}$ mixture) and was heated at $100^{\circ} \mathrm{C}$ until visible colors appeared (Stahl, 1969).

The biological (antimicrobial, antioxidant and antitumor) activities of the obtained fractions were determined as previously described.

\section{High performance liquid chromatography (HPLC)}

Preparative HPLC was used for isolation of pure compounds from the chosen fraction B obtained from column chromatography system, using LC-10AD VP SHIMADZU HPLC with purge pump and UV detector at $\lambda=220 \mathrm{~nm}$. The used column was reversed phase (Luna C-18, $250 \times 30 \mathrm{~nm}$ ) column, with typical flow rate 0.5 $\mathrm{ml} / \mathrm{min}$. About 40-100 mg of sub-fractions was dissolved in an appropriate amount of column mobile phase, then was injected to HPLC using a microsyringe. The solvent systems were 40$60 \%$ and $25-75 \% \mathrm{MeOH}-\mathrm{H}_{2} \mathrm{O}$, which are used isochratic-or- in gradient manner. The eluted peaks which were detected at different retention times by UV detector were collected separately in small vials. After each injection, column was washed with HPLC MeOH for $30 \mathrm{~min}$.

\section{Structure elucidation}

Structural elucidation of the isolated pure compounds was carried out by combination of spectroscopic techniques, mainly using 1D-NMR ( ${ }^{1} \mathrm{H}$ and ${ }^{13} \mathrm{C}$ NMR). The ${ }^{1} \mathrm{HNMR}$ measurement for pure compounds was performed in Deuterochloroform $\left(\mathrm{CDCl}_{3}\right)$ using a Varian 500 $\mathrm{MHz} .{ }^{1} \mathrm{HNMR}$ spectrum was referenced to TMS (tetra-methyl-silane) with chemical shift zero ppm. Structural assignments were based on spectra resulting from ${ }^{1} \mathrm{H}$ and ${ }^{13} \mathrm{C}$ NMR experiments. The observed chemical shift $(\delta)$ values were given in ppm and coupling constants $(\mathrm{J})$ in $\mathrm{Hz}$. The comparison of NMR data of pure compounds with other known published compounds was performed using the Reaxys databases and Sci finder database (Chemical Abstracts), which are available at web sites (https://www.reaxys.com), and (http://www.cas.org/products/scifindr/index. $\mathrm{html})$, respectively. 


\section{$\underline{\text { Results and Discussion }}$}

Out of twenty-five Aspergillus isolates, 19 were obtained from Giza Governorate $(\mathrm{G})$ agricultural soil and 6 from Saint Catherine Protectorate (S) soil. The identified isolates were denoted as follows: G1, Aspergillus flavus var. columnaris; G2, A. terreus; G3, A. terricola; G4, A. oryzae; G5, A. nidulans; G6, A. flavus var. flavus; G7, A. parasiticus; G8, A. niger; G9, A. stellifer; G10, A. japonicas; G11, A. nomius; G12, A. aculeatus; G13, A. fumigatus; G14, A. sydowii; G15, A. carbonarius; G16, A. violaceus; G17, A. tamarii; G18, A. candidus; G19, A. versicolor; S1, A. tamarii; S2, A. fumigatus; S3, A. niger; S4, A. oryzae; S5, A. sydowi; S6, A. flavus.

Biological activities of Aspergillus isolates extracts

Antimicrobial test

The growth of the gram positive strain Staphylococcus aureus was inhibited at $250 \mu \mathrm{g} /$ $\mathrm{ml}$ of fungal extracts of isolates G6, G7, G10, G12, G16, G17, S1 and S2, while at $125 \mu \mathrm{g} / \mathrm{ml}$ inhibition was caused by isolates G1, G2, G8 and G13. Fungal extract of G11 lead to inhibition at the least concentration $62.5 \mu \mathrm{g} / \mathrm{ml}$. The other fungal extracts had no inhibitory effects on the growth of $S$. aureus. Also, the growth of Bacillus subtilis was inhibited at $250 \mu \mathrm{g} / \mathrm{ml}$ of fungal extracts of isolates G6, G9, G12, G17, $\mathrm{S} 3, \mathrm{~S} 4, \mathrm{~S} 5$ and $\mathrm{S} 6$, while at $125 \mu \mathrm{g} / \mathrm{ml}$ inhibition caused by fungal isolates G1, G2, G3, G4, G7, $\mathrm{G} 16, \mathrm{G} 18, \mathrm{G} 19$ and S2. The dose $62.5 \mu \mathrm{g} / \mathrm{ml}$ of fungal isolates G5, G10 and G13 was lethal to B. subtilis. While G8 and G11 caused inhibition at the least concentration $31.25 \mu \mathrm{g} / \mathrm{ml}$. The other fungal extracts exhibited no inhibitory effects on B. subtilis (Fig. 1).

The responses of the gram negative strains varied with different fungal extracts, where the growth of Pseudomonas aeruginosa was inhibited at $250 \mu \mathrm{g} / \mathrm{ml}$ of extracts of fungal isolates G2, G4, G6, G9, G15, G16, G18 and S3, while it was inhibited at $125 \mu \mathrm{g} / \mathrm{ml}$ by extracts of fungal isolates G7, G8, G17 and S5. The most potent extract was that of G11, which inhibited the growth of the $P$. aeruginosa at $31.25 \mu \mathrm{g} /$ $\mathrm{ml}$. The other fungal extracts had no inhibitory effects on the growth. Klebsiella pneumonia was resistant to the all fungal extracts except for that of S2 and G15 at $250 \mu \mathrm{g} / \mathrm{ml}$, while G11 caused inhibition at $125 \mu \mathrm{g} / \mathrm{ml}$. Escherichia coli was also resistant to the all fungal extracts except to those of G1, G13 and S5 at $250 \mu \mathrm{g} / \mathrm{ml}$ and G11 at 62.5 $\mu \mathrm{g} / \mathrm{ml}$ extract concentration (Fig. 1). Alcaligenes faecalis was susceptible to seven fungal extracts out of twenty-five, where G1, G8, G13, G15, S2 and S5 inhibited the growth at $250 \mu \mathrm{g} / \mathrm{ml}$, while G11 inhibited the growth of $A$. faecalis at 125 $\mu \mathrm{g} / \mathrm{ml}$ (Fig. 1).

Candida albicans showed different responses towards the fungal extracts, where it was inhibited at $250 \mathrm{mg} / \mathrm{ml}$ of extracts of isolates G9, G11, G12 and G13 only and was resistant to the inhibitory effects of the others (Fig. 1).

In this connection, Rajalakshmi \& Mahesh (2014) concluded that Aspergillus terreus is a potential source of highest antibacterial phenol compounds used in biomedical applications. Also the endophytic isolate Aspergillus fumigatus $\mathrm{R} 7$ showed high antibacterial activity against Gram positive (B. subtilis [16 $\mathrm{mm}$ ], and $S$. aureus $[15 \mathrm{~mm}])$ and Gram negative bacteria (P. aeruginosa $[19 \mathrm{~mm}]$, and E. coli $[16 \mathrm{~mm}])$. In contrast, the isolate extract showed no activity against pathogenic fungi, A. niger, A. flavus, $C$. albicans (Lee et al., 2013).

Antioxidant activity using free radical scavenging (FRS) model

Three fungal extracts out of twenty-five had antioxidant activity, where the highest antioxidant extract was that of G11 $(60 \%$ scavenging activity), followed by those of G2 $(54 \%)$ and G9 (53\%). All other fungal extracts showed scavenging activity less than 50\% (Fig. 2).

In this regard, aromatic polyketide aspergillin $\mathrm{A}$ isolated from a marine sponge-derived fungus Aspergillus versicolor exhibited antioxidant activity comparable to that of butylated hydroxyanisole and significantly higher than that of Butylated hydroxytoluene (BHT). ( $\mathrm{Li}$ et al., 2011). Orcinol tetramer, tetraorcinol A, was isolated from the coral-associated strain $A$. versicolor, and showed radical-scavenging activity (Zhuang et al., 2011). An aromatic butenolides named Aspernolide J, was isolated from the metabolites of Aspergillus iizukae, which resided in the guts of cricket species Gryllus testaceus which showed significant activity with IC50 values of $29.46 \mathrm{mM}$, compared with the positive control trolox (IC50 $13.11 \mathrm{mM}$ ) (Li et al., 2016). 


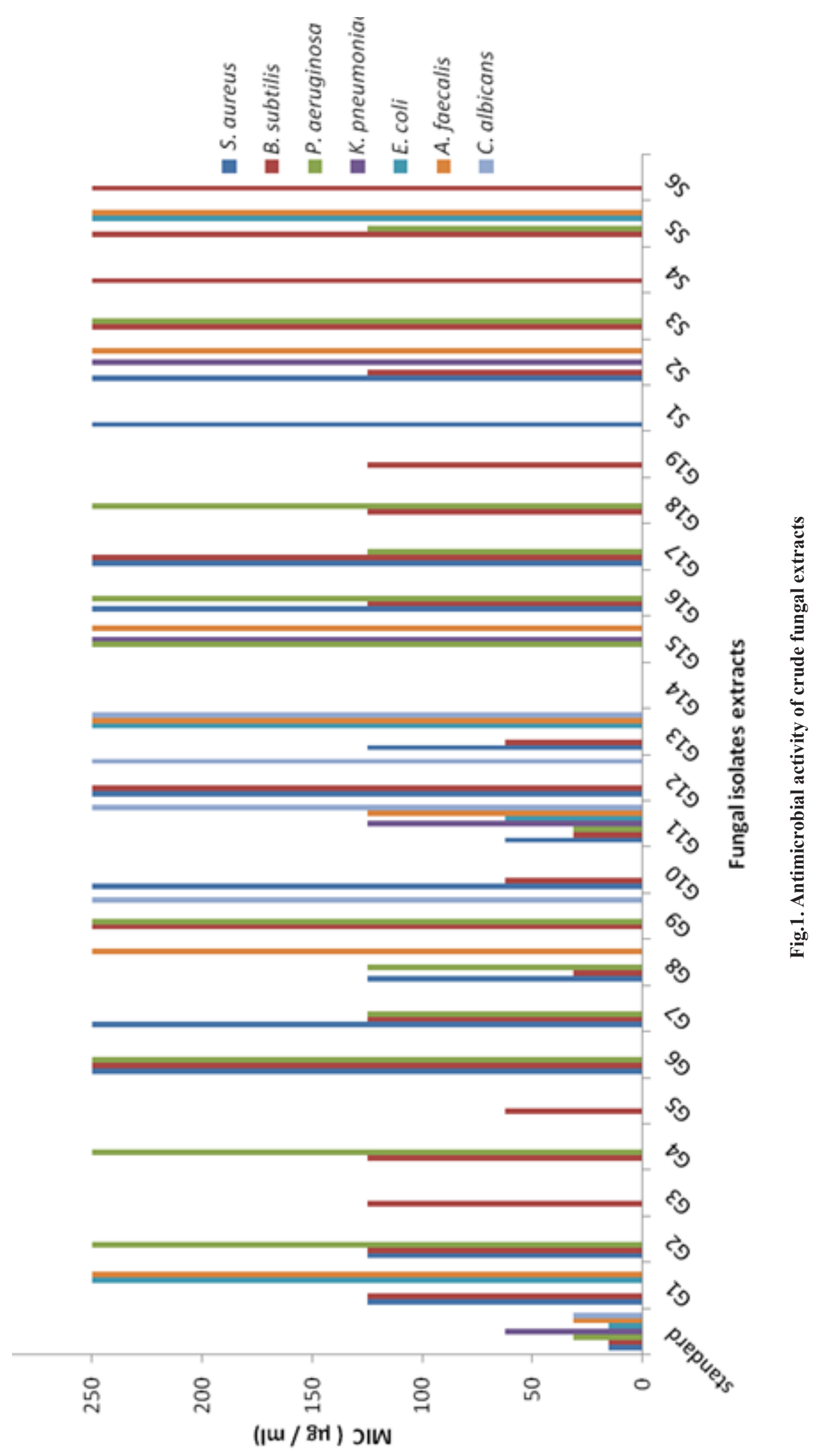

Egypt. J. Bot., Vol. 57, No. 3 (2017) 


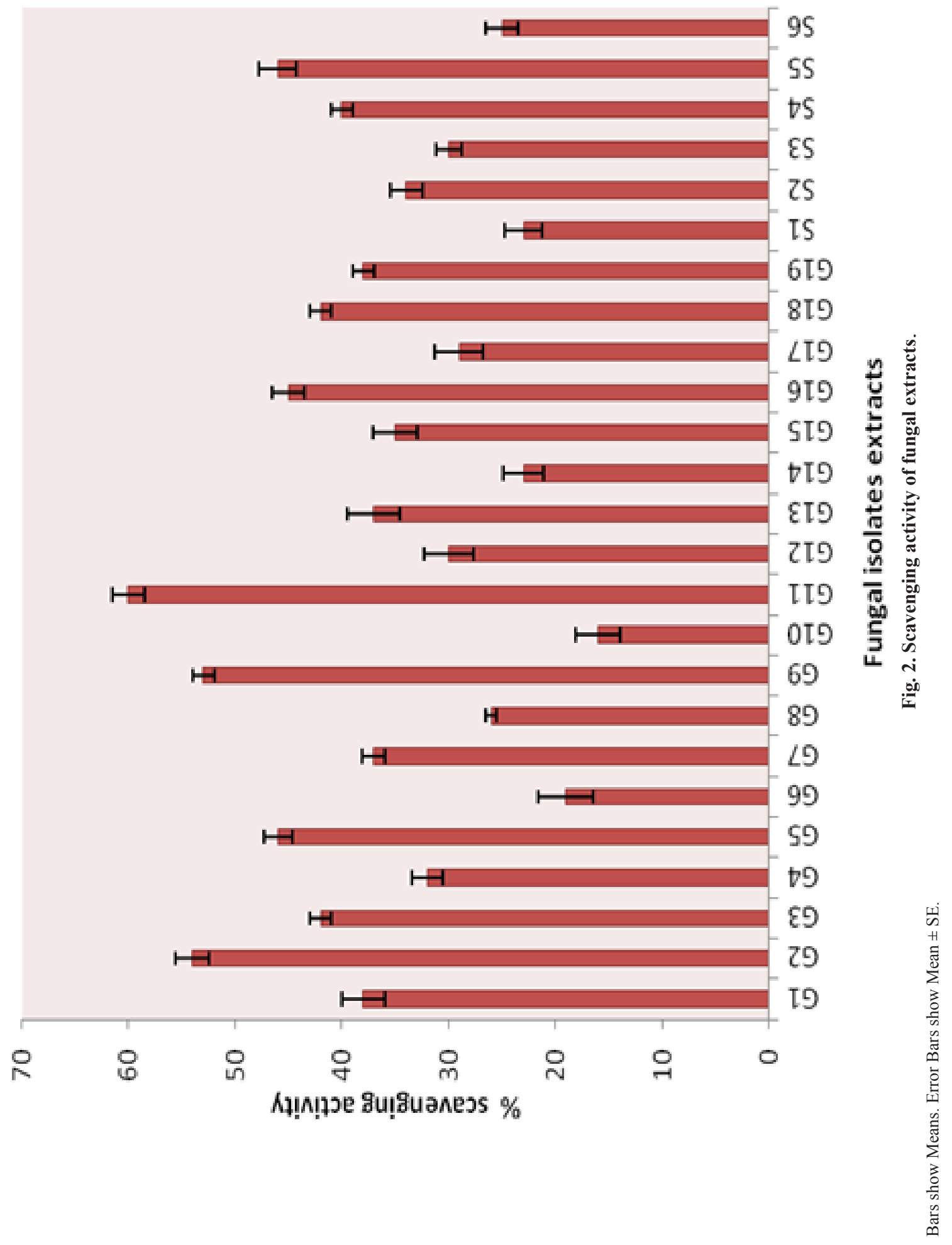


In vitro anticancer activity of the fungal extracts

In case of breast carcinoma cell line (MCF-7), the cell death reached $73.9 \%$ when treated with extract of the fungal isolate G2, followed by G11 by $72.3 \%$, then G4 by $70.2 \%$, while the breast carcinoma cell line death reached 69, 68.7 and $60.5 \%$ by G16, G18 and G8, respectively. The fungal extracts of isolates G17, G1 and G6 gave cell line death percentages of 55.2, 53 and 50.2\%, respectively (Fig. 3 a). The colon carcinoma cell line (HCT116) reached 69.1\% cell death when extract of the fungal isolate G8 was used, followed by $68.2 \%$ with isolate G11, G2 showed $63.7 \%$ and G13 showed $60.3 \%$ cell death. There were 5 fungal extracts showed cell death percentage above $50 \%$ which were G1, 55.7\%, G18, 55.1\%, G9, 51.9\%, G4, by $50.7 \%$ and $\mathrm{G} 16,50.1 \%$. The rest of fungal extracts led to cell death percentages less than $50 \%$ to the colon carcinoma cell line (HCT116) (Fig. 3 b). In case of liver carcinoma cell line (HEPG2), the fungal extract of isolate G11 showed the most potency as the cell death reached $80.1 \%$, then fungal isolates G9, G4 and G18 by $65.2,62.1$ and $62 \%$, respectively, followed by G1, S6, G6, S1 and G13 $(58.5,57,55.2,50.5$ and $50 \%$, respectively) (Fig. 3 c). While the extracts of the rest of fungal isolates showed percentages of cell death below $50 \%$.

It is worthy to mention that three diketopiperazines, 6-methoxyspirotryprostatin B. 18-oxotryprostatin A, and 14-hydroxyterezine were isolated from a marine wood-derived strain of Aspergillus sydowi. Compounds exhibited cytotoxicity against human lung adenocarcinoma (A-549) cells with IC50 values of 8.29, 1.28, and $7.31 \mu \mathrm{M}$, respectively, and compound Marineosin B also showed moderate cytotoxicity against Human promyelocytic leukemia cells (HL-cells), with an IC50 of $9.71 \mu \mathrm{M}$ (Zhang et al., 2008).

The $\alpha$-pyrone derivatives, nigerapyrones $\mathrm{B}$ and $\mathrm{E}$ were isolated from $A$. niger MA-132, an endophytic fungus obtained from the fresh tissues of the mangrove Avicennia marina. Nigerapyrone B showed moderate cytotoxicity against the HepG2 cell line with an IC50 of $62.0 \mu \mathrm{M}$, and compound Nigerapyrone $\mathrm{E}$ showed cytotoxicities against SW1990, MDA-MB-231, and A549 cell lines with IC50 values of 38,48 , and $43 \mu \mathrm{M}$ (Liu et al., 2011).

From the above results, fungal isolate G11 (Aspergillus nomius) was the most potent in antimicrobial, antioxidant and anticancer activities. Accordingly, it was chosen for further investigations.
Molecular identification of the most potent fungal isolate (G11)

The most potent fungal isolate G11 was phenotypically identified as Aspergillus nomius based on the comparison of its rDNA (18S rDNA gene) sequence with those in the DNA Data Bank of Japan (DDBJ). The phyllogentic tree (Fig. 4) showed high similarities of the fungal isolate G11 to Aspergillus nomius with accession number: LC199488 given at the DDBJ GenBank.

Aspergillus nomius is known to be human pathogenic as it was isolated form keratitis on Coimbatore India by Manikandan et al. (2009). Despite its potential as an aflatoxins producer, according to Frisvad et al. (2004), Aspergillus nomius showed pharmaceutical importance to produce aspergillic acid which is most commonly known as an antibiotic and antifungal agent, pseurotin which is known to have antiparasitic and anticancer activities. Tenuazonic acid was isolated from Aspergillus nomius and is known as a mycotoxin and a powerful eukaryotic protein synthesis inhibitor (Arora \& Arora, 2003). It was reported to produce kojic acid which is used in the manufacturing of sake, the Japanese rice wine, and is used in food and cosmetics to preserve or change colors of substances (Bentley, 2006).

Elucidation of the chemical structure of the most bioactive metabolite in Aspergillus nomius extract

Aspergillus nomius was cultivated on minimal medium (30 liter) using spore suspension. The culture filtrate was extracted with ethyl acetate (1:1, $\mathrm{v} / \mathrm{v}$ ). The extraction process was carried out three times for complete extraction. Fifteen grams was the net weight obtained after evaporation of the solvent from the crude extract from 30 litres medium.

The fifteen grams of crude extract were subjected to column chromatography for fractionation on reverse phase silica gel column (particle size 0.2$0.5 \mathrm{~mm}$ mesh size). The column was eluted using gradient solvent systems from $80 \% \mathrm{H}_{2} \mathrm{O}-20 \%$ methanol (MeOH) to $100 \% \mathrm{MeOH}$ (20\% stepwise), then the mobile phase was changed to methanol $(\mathrm{MeOH})$-ethyl acetate (EtOAc) in gradient manner until 100\% EtOAc. Two hundred and fifty $\mathrm{ml}$ fractions were eluted from column and collected. Where similar fractions were combined together according to their TLC profile, 13 fractions (A, B, C, D, E, F, G, H, I, J, K, L, and M) yielded. Based on the complexity of each fraction, the fractions A, B, $\mathrm{C}$, D, and $\mathrm{K}$ were selected for further investigation. 

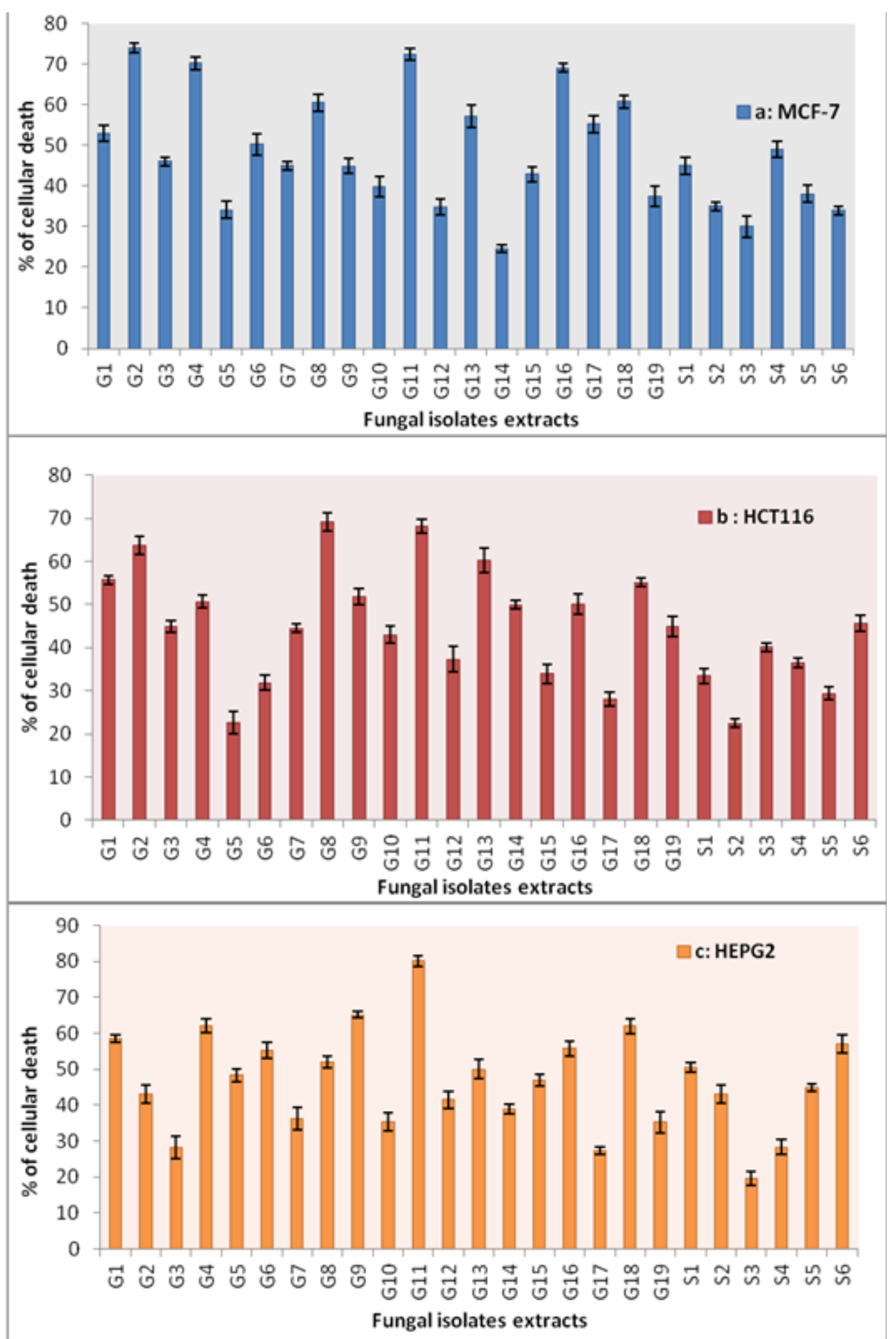

Fig. 3. Effect of fungal extracts on a : breast (MCF-7), b : colon (HCT116) and $\mathrm{c}$ : liver (HEPG2) carcinoma cell lines in vitro.

Bars show Means. Error Bars show Mean \pm SE. 


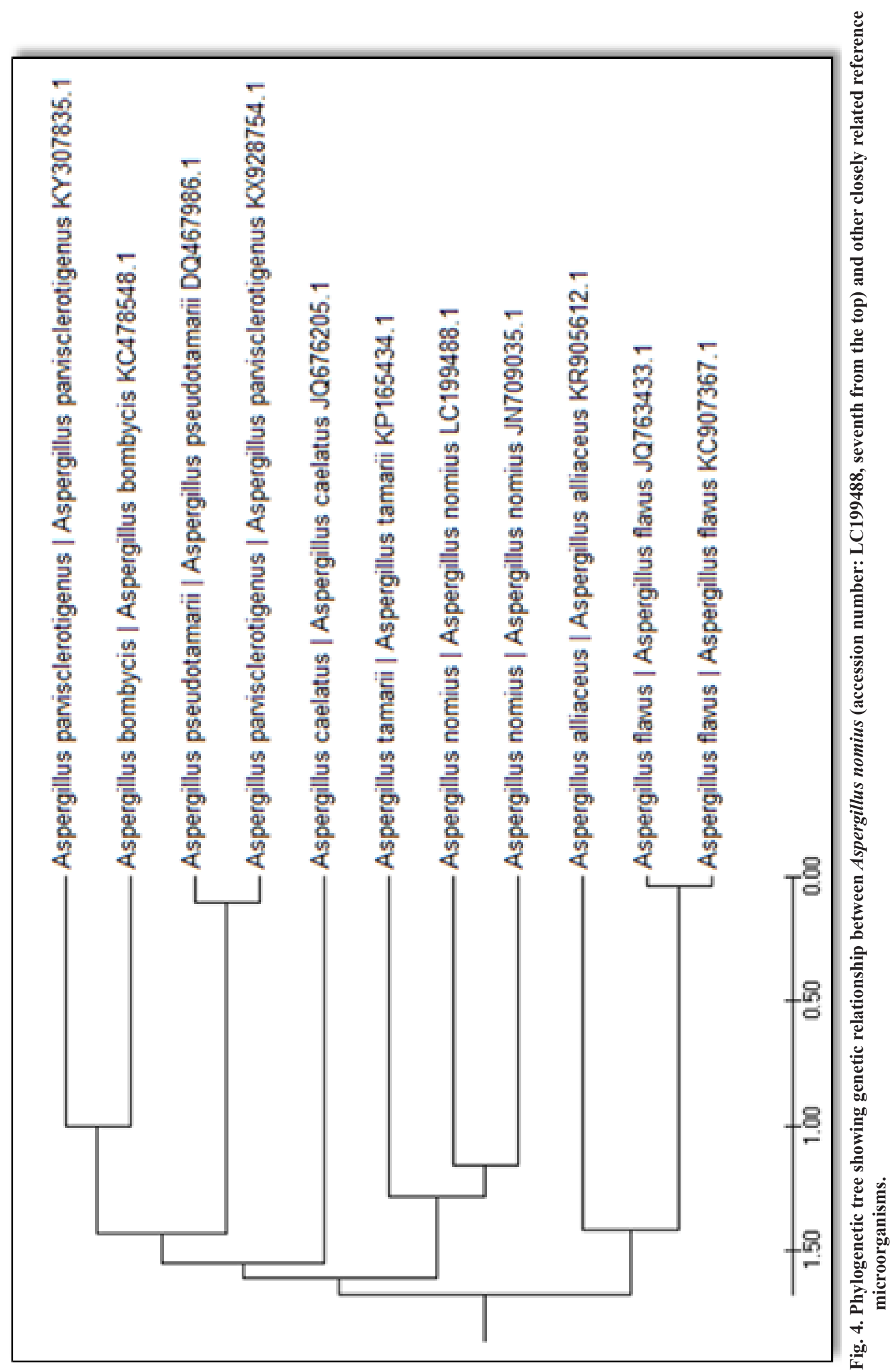

Egypt. J. Bot., Vol. 57, No. 3 (2017) 


\section{Antimicrobial activity of the fractions}

Results in Fig. 5, detected variations in the response of test organisms towards the different concentrations of the fractions. In case of $S$. aureus, fraction B was the most potent fraction which inhibited the growth at $62.5 \mu \mathrm{g} / \mathrm{ml}$, followed by fraction $\mathrm{D}$ at $125 \mu \mathrm{g} / \mathrm{ml}$, then fraction A at $250 \mu \mathrm{g} / \mathrm{ml}$, while fractions $\mathrm{C}$ and $\mathrm{K}$ were not inhibitory. In case of B. subtilis, fraction B showed the most potential activities that inhibited the growth at $31.25 \mu \mathrm{g} / \mathrm{ml}$, followed by fraction D at $125 \mu \mathrm{g} / \mathrm{ml}$, then fraction $\mathrm{K}$ at $250 \mu \mathrm{g} / \mathrm{ml}$. No inhibition was shown by fractions $\mathrm{A}$ and $\mathrm{C}$. However $P$. aeruginosa was susceptible to all fractions except fraction $\mathrm{K}$, where the growth was inhibited at $31.25 \mu \mathrm{g} / \mathrm{ml}$ by fraction $\mathrm{B}$, then at $250 \mu \mathrm{g} / \mathrm{ml}$ for fractions A, C and D. In case of $K$. pneumoniae, it was inhibited only by fraction $\mathrm{A}$ at $250 \mu \mathrm{g} / \mathrm{ml}$ and fraction B at $125 \mu \mathrm{g} / \mathrm{ml}$. E. coli was susceptible to all the fractions: fraction $\mathrm{B}$ at 62.5 $\mu \mathrm{g} / \mathrm{ml}, \mathrm{A}$ at $125 \mu \mathrm{g} / \mathrm{ml}$, fractions and C, D and $\mathrm{K}$ at $250 \mu \mathrm{g} / \mathrm{ml}$, while $A$. faecalis was susceptible only with fraction B at $62.5 \mu \mathrm{g} / \mathrm{ml}$. C. albicans was susceptible to all the fractions except $\mathrm{K}$, as fractions A and B caused inhibition at $125 \mu \mathrm{g} / \mathrm{ml}$, while fractions $\mathrm{C}$ and $\mathrm{D}$ inhibited growth at 250 $\mu \mathrm{g} / \mathrm{ml}$ (Fig. 5).

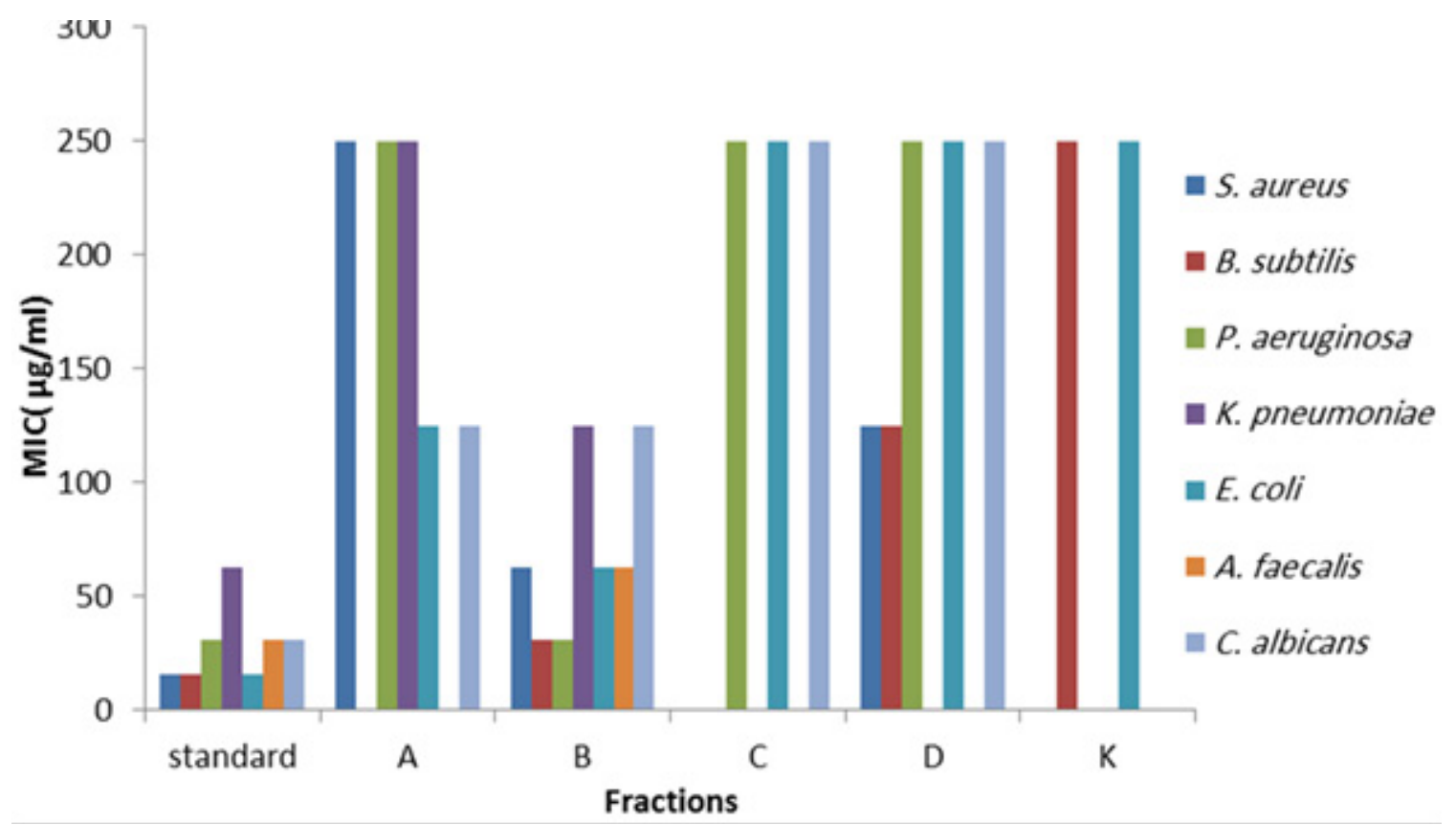

Fig. 5. Antimicrobial activity of the five selected fractions. Antioxidant activity using free radical scavenging (FRS) model

It could be concluded that fraction B proved to be the most potential antimicrobial fraction and was active against all the tested pathogens.

The antioxidant activity was assessed for all fractions and the activity was measured at a concentration of $100 \mu \mathrm{g} / \mathrm{ml}$ of crude extracts.

Only fraction B out of the five fractions had antioxidant activity (60\% scavenging activity), while the rest of fractions showed scavenging activities less than 50\% (Fig. 6).

Anticancer test for the fractions

The cellular toxicity of fractions was assessed in vitro by Skehan et al. (1990) assay. Single dose experiments of the five fractions were carried out on breast carcinoma cell line (MCF7), colon carcinoma cell line (HCT116), and liver carcinoma cell line (HEPG2).

In case of MCF-7 the cell death reached $75.1 \%$ when tested against fraction $\mathrm{B}$, followed by $49.1 \%$ by fraction $A, 40.1 \%$ by fraction $D$, $32.9 \%$ by fraction $\mathrm{C}$, and finally $28 \%$ by fraction K. Meanwhile HCT116 reached $65.7 \%$ cell death with fraction $\mathrm{B}$, followed by $55 \%$ cell death using fraction C. Fractions K, A and D showed 34.9\%, $30.5 \%$ and $25 \%$ cell death, respectively. In case of HEPG2, fraction B showed the most potency as the cell death reached $80 \%$, then came fractions $\mathrm{D}, \mathrm{K}, \mathrm{A}$ and $\mathrm{C}$ by $57.1 \%, 46.9 \%, 40.1 \%$ and $26.5 \%$, respectively (Fig. 7). 


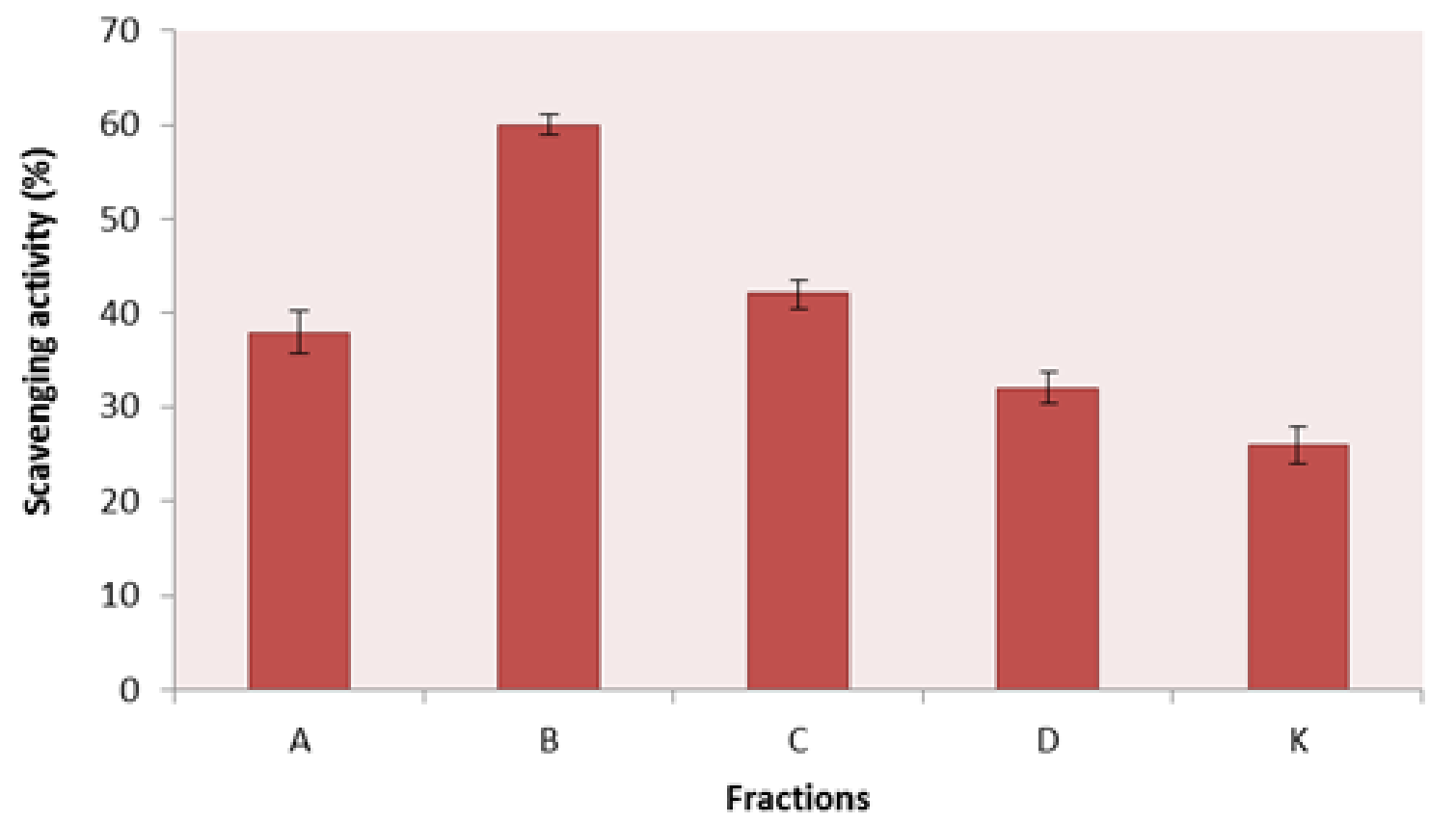

Fig. 6. Figure 6: Scavenging activity of the five selected fractions.

Bars show Means. Error Bars show Mean \pm SE.

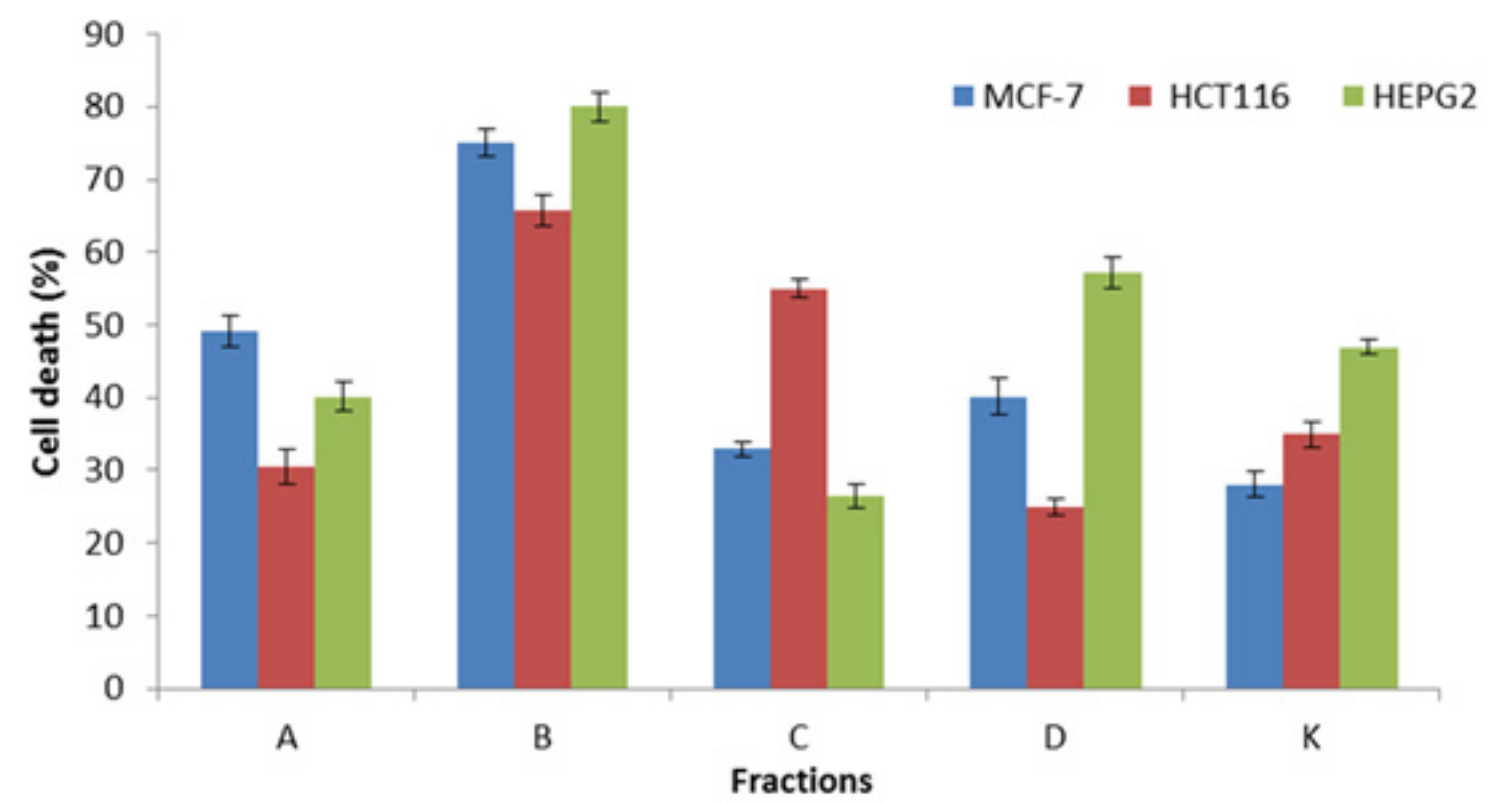

Fig. 7. Effect of the five selected fractions on breast (MCF-7), colon (HCT116) and liver (HEPG2) carcinoma cell lines in vitro.

Bars show Means. Error Bars show Mean \pm SE.

In this regards the endophytic Aspergillus sp. had an IC 50 of $22.73 \mu \mathrm{g} / \mathrm{ml}$, while the plant extract had an IC 50 of $6.25 \mu \mathrm{g} / \mathrm{ml}$. The phytochemical screening of the extracts showed the presence of phenols, flavonoids, alkaloids, tannins and glycosides. The study indicated the presence of anticancer compounds in the plant and its endophytic Aspergillus sp. The endophyte was shown to possess bioactivity three times than that of the host plant (Prabavathy \& Vallinachiyar, 2013). 
From the aforementioned results fraction $\mathrm{B}$ was the most active fraction so it was subjected to HPLC for investigating its active compound (s).

\section{High performance liquid chromatography (HPLC)}

Based on the TLC fractions, B was subjected to preparative HPLC using isocratic $40 \%$ MeOH: $60 \% \mathrm{H}_{2} \mathrm{O}$ solvent system at $220 \mathrm{~nm}$, and the results showed that there was a sharp peak at about $18.1 \mathrm{~min}$ in $\mathrm{B}$ fraction which indicated the probability of presence of a promising compound. So this peak was picked up and subjected to more purification (Fig. 8).

In this connection, the chemical profiling indicated that Aspergillus sp. is a rich source of alkaloids, terpenoids, xanthones, and polyketides. Some of these showed interesting biological activities such as antifungal, antibacterial, antifouling, and cytotoxic activities (Wang et al., 2011 and He et al., 2012). Species of the genus Aspergillus aer known to produce alkaloids with pyrazino[2,1-b]quinazoline-3,6-dione system. Among them glyantrypine was isolated from $A$. clavatus (Penn et al., 1992), fumiquinazolines A-G from A. fumigatus (Takahashi et al., 1995). Two new alkaloids carnequinazolines were determined as quinazolinone with additional oxidation and alkylation patterns in their molecules were isolated from A. carneus KMM 4638, obtained from the marine brown alga Laminaria sachalinensis (Zhuravleva et al., 2012). Cottoquinazoline $D$, a new alkaloid with a 1-aminocyclopropane-1-carboxylic acid residue rarely discovered in nature, was isolated and identified together with two new quinazolinone alkaloids, cottoquinazolines $\mathrm{B}$ and $\mathrm{C}$, from coral-associated fungus $A$. versicolor LCJ-5-4 (Zhuang et al., 2011).

From the above results the sharp and clear peak at about $18.1 \mathrm{~min}$ in fraction $\mathrm{B}$ was separated using HPLC and subjected to ${ }^{13} \mathrm{CNMR}$ and ${ }^{1}$ HNMR spectroscopy.

\section{${ }^{1} H N M R$ and ${ }^{13} C N M R$ for the pure peak obtained fraction $B$}

Figure 9 a depicts the results of ${ }^{1} \mathrm{HNMR}$ spectroscopy. The observed chemical shift $(\delta)$ values for protons are given in ppm. The ${ }^{1} \mathrm{HNMR}$ was carried out for the sharp peak purified from fraction $\mathrm{B}$, at $200 \mathrm{MHz}, \mathrm{CDCl}_{3}: \delta=8.41$ $\left(\mathrm{s}, 1 \mathrm{H}, \mathrm{D}_{2} \mathrm{O}\right.$ exchangeable, $\left.\mathrm{OH}\right), 7.12-7.27(\mathrm{~m}$, $4 \mathrm{H}, \mathrm{ArH}), 4.91-4.95$ (m, 1H, H-3), 4.78 (m,
1H, H-1b), 3.86 (br s, 2H, $\left.\mathrm{CH}_{2}-9\right), 3.52(\mathrm{~m}, 1 \mathrm{H}$, H-1a), 2.45 (m, 1H, H-2a), 1.95 (m, 1H, H-2b). The ${ }^{13} \mathrm{CNMR}$ spectrum (Fig. 9 b) confirmed the structure of the purified compound. It was carried out at $75 \mathrm{MHz}, \mathrm{CDCl}_{3}: \delta=28.8(\mathrm{C}-2)$, 46.2 (C-1), 49.9 (C-9), 70.6 (C-3), 118.0, 119.2, 126.1, 127.1, 129.1, 141.9 (C-4a), and 163.6 (C-3a). These results were compared with other known published compound at Reaxys databases at Sci finder database (chemical abstracts). The pure compound of the sharp peak in fraction $\mathrm{B}$ is likely a quinazoline alkaloid which is 1,2,3,9 tetrahydropyrrolo[2,1-b]quinazolin-3-ol (Fig.10).

Vasicine, vasicinone and peganin are alkaloids with similar formula to the obtained compound in the present study. Vasicine has been obtained in vitro for the first time from leafand petiole derived callus cultures of Adhatoda zeylanica (Jayapaul et al., 2005). Vasicinone was isolated from Justicia adhathoda (Mehta et al., 1963) and Peganum harmala (Astulla et al., 2008). Peganine was isolated from Peganum harmala (Tozhibaev et al., 2006) and from Nitraria schoberi (Tulyaganov \& Kozimova, 2005).

Vasicine exhibited strong antioxidant activity with very low $\mathrm{IC}_{50}$ vlaue, in Ames assay that used to explore the antimutagenic activity. It was seen that vasicine exhibited dose dependant antimutagenic activity against aminofluorine (S9 dependent mutagen) include mutation in TA98 and TA100 Salmonella typhimuruim strain of $\%$ maximum inhibition of $98.08 \pm 0.088 \%$ and $87.3 \pm 0.0661 \%$, respectively. It showed also cytotoxic effect in PC-3 cancer cells as well as loss of mitochondrial membrane potential and the feature typical of apoptosis (Kaur et al., 2016). Vasicine also has pharmacological activities in bronchial asthma relief for long time, Vasicinone have showed pharmacological activities as a bronchodilator (Pa \& Mathew, 2012).

In conclusion, it is worthy to mention that the compound 1,2,3,9-tetrahydropyrrolo[2,1-b] quinazolin-3-ol which is much similar to vasicine and peganin is isolated for the first time, as far as the authors are aware, from Aspergillus nomius (accession no. in DDBJ: LC199488). This fungus was isolated from an agricultural soil in Giza Governorate, Egypt, and showed antioxidant, antimicrobial and anticancer activities. 


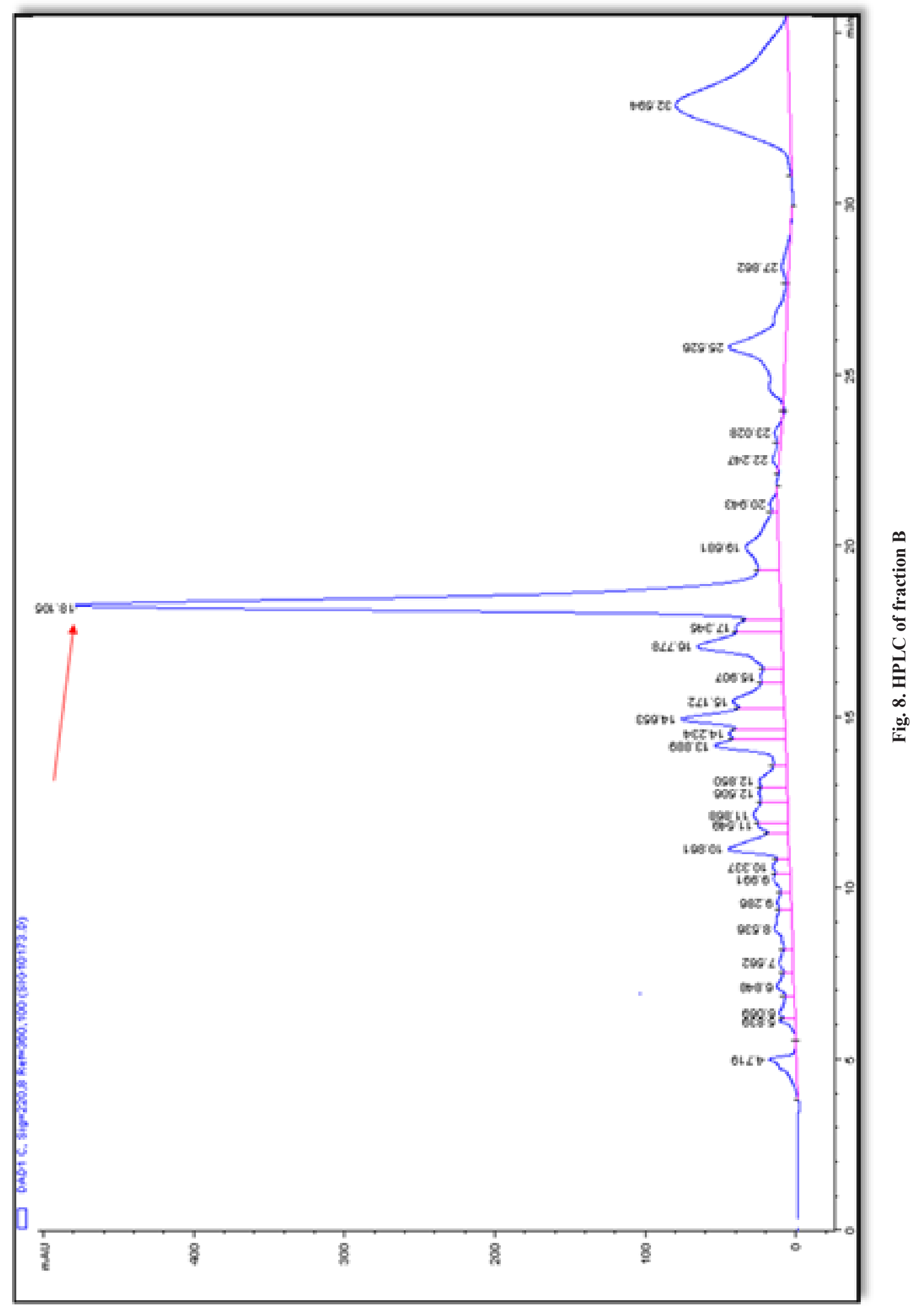

Egypt. J. Bot., Vol. 57, No. 3 (2017) 


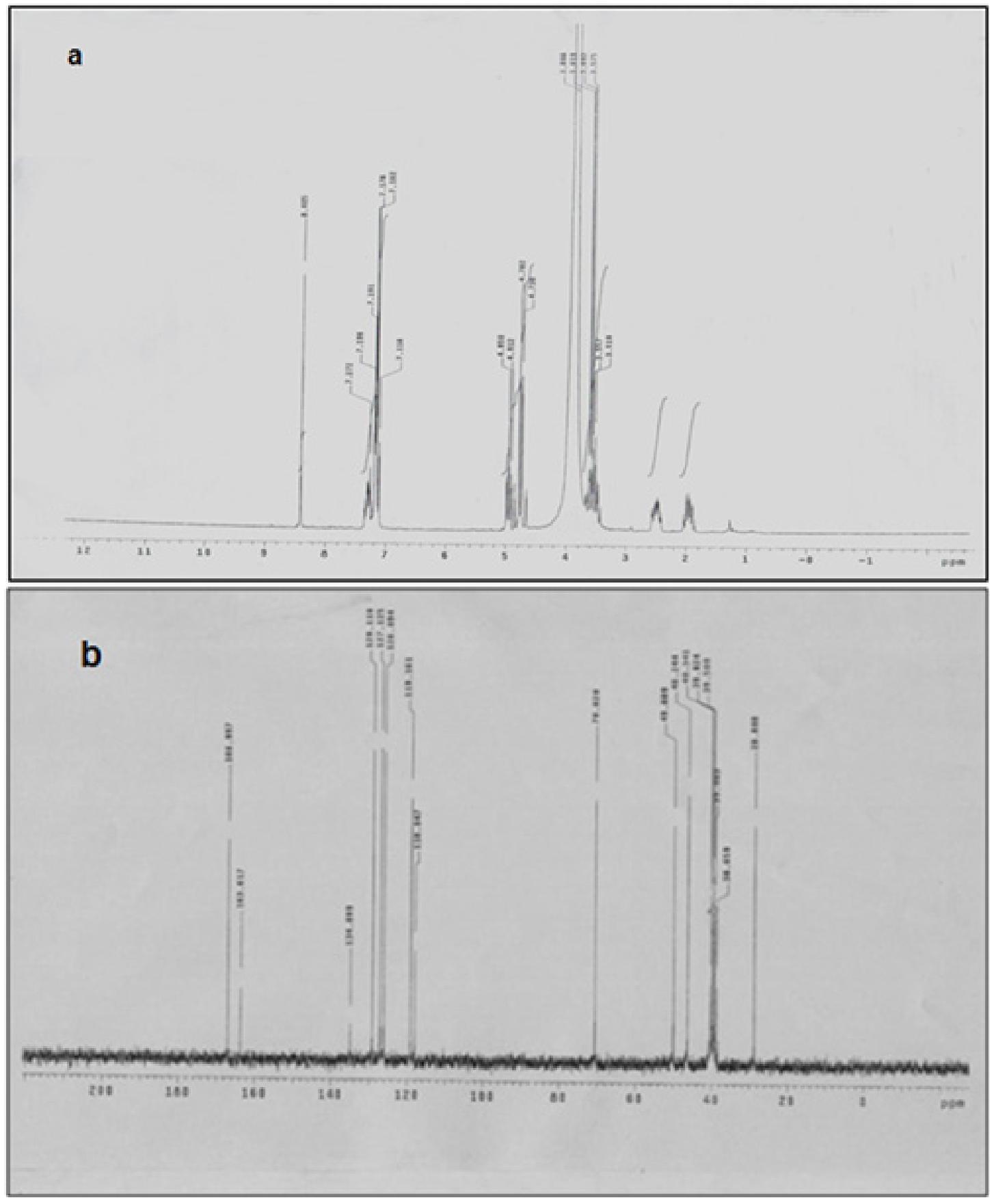

Fig. 9. ${ }^{1} \mathrm{HNMR}$ (a) and ${ }^{13} \mathrm{CNMR}$ (b) spectra of the purified peak of fraction B.<smiles>[Y]c1ccc2c(c1)CN1CC[C@H](O)C1=N2</smiles>

Fig. 10. Deduced structure of the purified 1,2,3,9 tetrahydropyrrolo [2,1-b] quinazolin-3-ol compound. 


\section{References}

Arora, D.K. and Arora, K.A. (2003) "Fungal Biotechnology in Agricultural, Food, and Environmental Applications". Marcel Dekker Inc. $1^{\text {st }}$ ed. New York, USA.

Astulla, A., Zaima, K., Matsuno, Y., Hirasawa, Y., Ekasari, W., Widyawaruyanti, A., Zaini, N.C. and Morita, H. (2008) Alkaloids from the seeds of Peganum harmala showing antiplasmodial and vasorelaxant activities. Journal of Natural Medicines, 62, 470-472.

Bentley, R. (2006) From miso, sake and shoyu to cosmetics: a century of science for kojic acid. Nat. Prod. Rep. 23, pp.1046-1062.

Borneman, J. and Hartin, R.J. (2000) PCR primers that amplify fungal rRNA genes from environmental samples, American Society for Microbiology Applied and Environmental Microbiology, 66, 4356-60.

Campoy, S., Sierra, S., Suarez, B., Ramos, M.C., Velasco, J., Burgos, J.S. and Adrio, J.L. (2010) Semisynthesis of novel monacolin $\mathrm{J}$ derivatives: hypocholesterolemic and neuroprotective activitie. The Journal of Antibiotics, 63, 499-505.

Frisvad', J.C., Smedsgaard, J., Larsen, T.O. and Samson, R.A. (2004) Mycotoxins, drugs and other extrolites produced by species in Penicillium subgenus Penicillium. Stud. Mycol. 49, 201-241.

Furtado, N.A., Said, S., Ito, I.Y. and Bastos, J.K. (2002) The antimicrobial activity of Aspergillus fumigatus is enhanced by a pool of bacteria. Microbiological Research Journal, 157, 207-11.

Hamed, A. (2009) Investigation of multiple cytoprotective actions of some individual phytochemicals and plant extracts. (PhD Thesis Biomedical Sciences), Nottingham University, United Kingdom.

Hayes, M., Wrigley, S., Chetland, I., Renyolds, E., Ainsworth, A., Renno, D., Latif, M., Cheng, X., Hupe, D., Charlton, P. and Doherty, A.M. (1995) Novel drimane sesquiterpene esters from Aspergillus ustus var. pseudodeflectus with endothelin receptor binding activity. Journal of Antibiotics, 49, 505-512.

He, F., Sun, Y.L., Liu, K.S., Zhang, X.Y., Qian, P.Y., Wang, Y.F., Qi, S.H. and Antibiot, J. (2012) Indole alkaloids from marine-derived fungus Aspergillus sydowii SCSIO 00305. The Journal of Antibiotics, 65, 109-111.
Houbraken, J., Due, M., Varga, J., Meijer, M., Frisvad, J.C. and Samson, R.A. (2007) Polyphasic taxonomy of Aspergillus section Usti. Studies in Mycology, 59, 107-128.

Jayapaul, K., Kishor, K.P.B. and Reddy, K.J. (2005) Production of pyrroloquinazoline alkaloid from leaf and petiole-derived callus cultures of Adhatoda zeylanica. In Vitro Cellular \& Developmental Biology. Plant, 41, 682-685.

Johnson, L.F., Curi, E.A., Bond, J.H. and Fribourg, H.A. (1960) "Methods for Studying Soil Microflora-Plant Disease Relationship". $1^{\text {st }}$ ed. Burgess Publishing, Minneapolis, USA.

Kaur, A., Katoch, D., Singh, B. and Arora, S. (2016) Seclusion of vasicine- and quinazoline alkaloid from bioactive fraction of Justicia adhathoda and its antioxidant, antimutagenic and anticancerous activities. Journal of Global Biosciences, 5, 3836-3850.

Kohno, J., Hiramastu, H., Nishio, M., Sakurai, M., Okuda, T. and Komatsubara, S. (1999a) Structures of TMC-120 A, B, C, novel isoquinoline alkaloids from Aspergillus ustus TC 1118. Tetrahedron, 55, 11247-11252.

Kohno, J., Sakurai, M., Kameda, N., Nishio, M., Kawano, K., Kishi, N., Okuda, T., Komatsubara, S, (1999b) Production, isolation and biological properties of TMC-120A, B, C, novel inhibitors of eosinophil survival from Aspergillus ustus TC 1118. Journal of Antibiotics, 52, 913-916.

Lee, Y.M., Kim, M.J., Li, H., Zhang, P., Bao, B., Lee, K.J. and Jung, J.H. (2013) Marine-derived Aspergillus species as a source of bioactive secondary metabolites. Marine Biotechnology, 15, 499-519.

Li, J.L., Lee, Y.M., Hong, J., Bae, K.S., Choi, J.S. and Jung, J.H. (2011) A new antioxidants from the marine sponge-derived fungus Aspergillus versicolor. Nat. Prod. Sci. 17, 14-18.

Li, L., Li, T., Kong, L. and Yang, M. (2016) Antioxidant aromatic butenolides from an insect-associated Aspergillus iizukae. Phytochemistry Letters, 16, 134-140.

Liu, D., Li, X.M., Meng, L., Li, C.S., Gao, S.S., Shang, Z., Proksch, P., Huang, C.G. and Wang, B.G. (2011)Nigerapyrones A-H, alpha-pyrone derivatives from the marine mangrove-derived endophytic fungus Aspergillus niger MA-132. J. Nat. Prod. 74,1787-1791.

Machida, M. and Gomi, K. (2010) Aspergillus: Molecular 
Biology and Genomics. Mycology, 1, 283.

Manikandan, P., Varga, J., Kocsubé, S., Samson, A.R., Anita, R., Revathi, R., Dóczi, I., Németh, M.T., Narendran, V., Vágvölgyi, C., Manoharan, C. and Kredics, L. (2009) Mycotic keratitis due to Aspergillus nomius. Journal of Clinical Microbiology, 47, 3382-3385.

McFarland, J. (1907) Nephelometer: an instrument for estimating the number of bacteria in suspensions used for calculating the opsonic index and for vaccines. J. Am. Med. Assoc. 14, 1176-11768.

Mehta, D.R., Naravane, J.S. and Desai, R.M. (1963) Vasicinone. A bronchodilator principle from Adhatoda vasica Nees (N. O. Acanthaceae). The Journal of Organic Chemistry, 28, 445-448.

Moubasher, A.H. (1993) "Soil Fungi in Qatar and Other Arab Countries". Centre for Scientific and Applied Research. University of Qatar.

Nielsen, K.F. and Mogensen, J.M. (2009) Review of secondary metabolites and mycotoxins from the Aspergillus niger group. Anal Bioanal Chemitery, 395, 1225-1242.

Ogawa, A., Murakami, C., Kamisuki, S., Kuriyama, I., Yoshida, H., Sugawara, F. and Mizushina, Y. (2004) Pseudodeflectusin, a novel isochroman derivative from Aspergillus pseudodeflectus a parasite of the sea weed, Sargassum fusiform, as a selective human cancer cytotoxin. Bioorg. Med. Chem. Lett. 14, 3539-3543.

Osman, M.E., Sallam, L.A.R., Ahmed, W.A., Khttab, O.H. and Abo EL-Nasser, A.A. (2007) Aspergillus fumigatus and Cylindrocarpon candidum fungi induced apoptosis in HEPG 2 cell line through activation of caspases enzymes. Egyptian Society for Biotechnology, 26.

Pa, R. and Mathew, L. (2012) Antimicrobial activity of leaf extracts of Justicia adhatoda L. in comparison with vasicine. Asian Pacific Journal of Tropical Biomedicine, 2, 1556-1560.

Penn, J., Mantle, P.G., Bilton, J.N. and Sheppard, R.N. (1992) Glyantrypine, a novel anthranilic acidcontaining metabolite of Aspergillus clavatus. J. Chem. Soc. Perkin Trans. 1, 1495-1496

Prabavathy, D. and Vallinachiyar, C. (2013) Cytotoxic potential and phytochemical analysis of Justicia beddomei and its endophytic Aspergillus sp., Asian Journal of Pharmaceutical and Clinical Research, 6, 159-161
Pontecorvo, G., Roper, J.A., Hemmons, L.M., Macdonald, K.D. and Bufton, A.W. (1953) The genetics of Aspergillus nidulans. Adv. Genet. 5, $141-238$

Rajalakshmi, S. and Mahesh, N. (2014). Production and characterization of bioactive metabolites isolated from Aspergillus terreus in rhizosphere soil of medicinal plants, International Journal of Current Microbiology and Applied Science, 3, 784-798.

Raper, K.B. and Fennell, D.I. (1965) "The Genus Aspergillus". (Baltimore: Williams \& Wilkins). USA.

Sahin, F., Karaman, I., Gulluce, M., Ogutcu, H., Sengul, M., Adiguzel, A., Ozturk, S. and Kotan, R. (2003) Evaluation of antimicrobial activities of Satureja hortensis L. Journal of Ethnopharmacology, 87, 61-65.

Skehan, P., Storeng, R., Scudiero, D., Monks, A. and McMahon, J. (1990) New colorimetric cytotoxicity assay for anticancer-drug screening. J. Natl. Cancer Inst. 82, 1107-1112.

Slack, G.J., Puniania, E., Frisvad, J.C., Samson, R.A. and Miller, J.D. (2009) Secondary metabolites from Eurotium species, Aspergillus calidoustus and A. insuetus common in Canadian homes with a review of their chemistry and biological activities. British Mycological Society, 113, 480-490.

Stahl, E. (1969) "Thin Layer Chromatography", $2^{\text {nd }}$ ed. A Laboratory Handbook Springer, New York.

Takahashi, C., Matsushita, T., Doi, M., Minoura, K., Shingu, T., Kumeda, Y. and Numata, A. (1995) Fumiquinazolines A-G, novel metabolites of a fungus separated from a Pseudolabrus marine fish. J. Chem. Soc. Perkin Trans. 1, 2345-2353.

Thom, C. and Raper, K.B. (1945) "A Manual of the Aspergilli". (Baltimore: Williams \& Wilkins).USA.

Tozhibaev, A.G., Turgunov, K.K., Tashkhodzhaev, B. and Shakhidoyatov, K.M. (2006) Structures of deoxypeganine salts. Chem. Nat. Compd. 42, 340344.

Tulyaganov, T.S. and Kozimova, N.M. (2005) Alkaloids from Nitraria schoberi. O-acetylnitraraine. Chem. Nat. Compd. 41, 578-579.

Wang, Y., Zheng, J.K., Liu, P.P., Wang, W. and Zhu, W.M. (2011) Three new compounds from Aspergillus terreus PT06-2 grown in a high salt medium. Marine Drugs, 9, 1368-1378. 
Yang, L., Lübeck, M. and Lübeck, P.S. (2017) Aspergillus as versatile cell factory for organic acid production. Fungal Biology Review. 31, 33-49.

Zhang, Y.P., Ling, S., Fang, Y.C., Zhu, T.J., Gu, Q.Q. and Zhu, W.M. (2008) Isolation, structure elucidation, and antimycobacterial properties of dimeric naphtho-gamma-pyrones fromthemarinederived fungus Aspergillus carbonarius. Chem Biol. 5, 93-100.
Zhuang, Y.B., Teng, X.C., Wang, Y., Liu, P.P., Wan, H., Li, G.Q. and Zhu, W.M. (2011) Cyclopeptides and polyketides from coral-associated fungus, Aspergillus versicolor LCJ-5-4. Tetrahedron. 67, 7085-7089.

Zhuravleva, O.I., Afiyatullov, S.S., Denisenko, V.A., Ermakova, S.P., Slinkina, N.N., Dmitrenok, P.S. and Kim, N.Y. (2012) Secondary metabolites from a marine-derived fungus Aspergillus carneus Blochwitz. Phytochemistry, 80, 123-131.

(Received 11 / 5 /2017, accepted 12/9/2017)

\title{
الانشطة الحيوية لأكالويد كينازولين من اسبرجلس نوميس
}

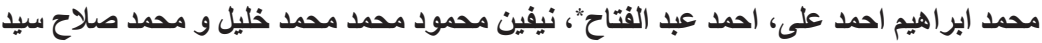

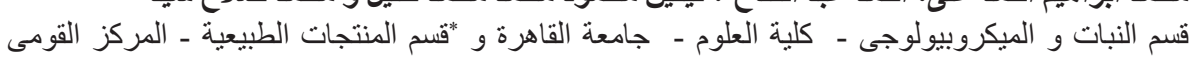 \\ للبحوث ـ الجيزة - مصر البروبات
}

\begin{abstract}
تم عزل خمسة و عشرين عزلة اسبرجلس من تربتين من محافظة الجيزة ومن محمية سانت كاترين فى مصر .

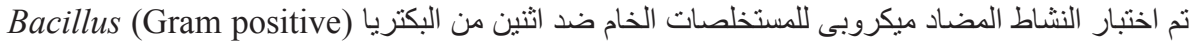
Gram) و اربعة من البكتريا Subtilis NRRL-B-4219, Staphylococcus aureus ATCC29213 Alcaligenes faecalis B-170, Escherichia coli ATCC25922, Klebsiella (negative spneumoniae ATCC 10131, Pseudomonas aeruginosa ATCC27953 ) free radical Candida albicans ATCC10231 Scavenging

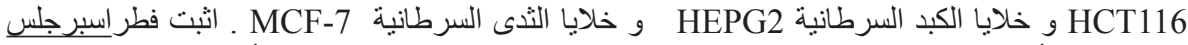

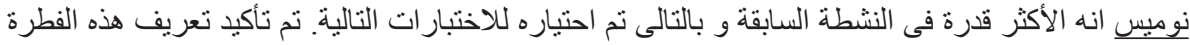

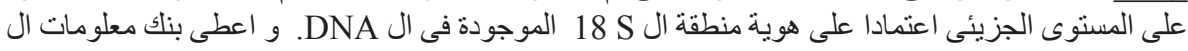
DNA

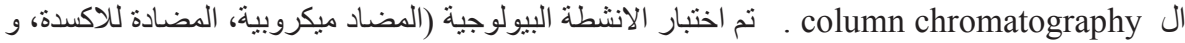

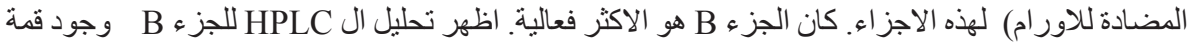

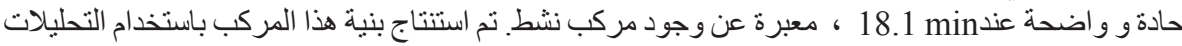

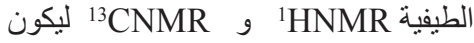
.1,2,3,9 tetrahydropyrrolo [2,1-b] quinazolin-3-ol.
\end{abstract}

